\title{
WNT3 wt Allele
}

National Cancer Institute

\section{Source}

National Cancer Institute. WNT3 wt Allele. NCI Thesaurus. Code C52996.

Human WNT 3 wild-type allele is located within 17q21-q22 and is approximately $54 \mathrm{~kb}$ in length. This allele, which encodes proto-oncogene wnt-3 protein, is involved in fetal development. 